\title{
Ceremonies and Festive Celebrations in the School
}

Otto F. Bollnow

University of Tübingen

\section{The Neglect of School Ceremonies and Festive Celebrations}

In the following pages I direct our interest toward moods which have a temporal character and which reveal themselves to us in their distinctiveness from the everyday existence of ordinary life. I mean ceremonies and celebrations (Bollnow, 1955). We do not want to reduce the significance of celebrations to mere moods; still, it is these moods which provide the key to unlocking the deeper understanding of ceremonies and celebrations. Moreover, ceremonies and celebrations are not just minor matters; rather, they prove the Heideggerian thesis that the primary unlocking of the world is found fundamentally only by way of pure moods (Heidegger, 1927). This relationship has likewise a considerable pedagogical consequence which affects the natural togetherness of family life and continues onward into school life.

If we look back into the history of pedagogy, we notice that ceremonies and festive celebrations have played a significant role in school life. In the accounts which we have about school life in the middle ages, school celebrations were extremely important. Even in the school reports of the Philanthrops there is much talk of celebrative school festivities. However, in more recent developments their significance has been seriously disregarded. One could hardly say that ceremonies and celebrations in today's schools are an important matter. The great church celebrations-Christmas, Easter, and Pentecost-are separated from school life through the arrangement of holidays. They have become family events rather than school happenings. Very little remains for the school. There are the school-leaving celebrations, in which the students, after regular examinations, are sent off from their old school with best wishes for their future. The means of these school-leaving celebrations were and are rather paltry: In the midpoint stood the ceremonial presentation which was often connected only loosely with the occasion of this day; it was framed by some songs performed by the school choir, and was then completed with a few poems. There was no great effort behind these celebrations. They were rather 
joyless events in which one more or less dutifully accepted one's fate.

That this did not satisfy the high school students is evident from their behavior. On their own, on various occasions and especially after regular final examinations, they tried to celebrate again. In the earlier years there was usually a free-for-all with a glass of beer to which even the teachers were invited. Later on it probably became an occasion for a dance. The spontaneous get-together was more than likely an extension of normal student life at that time, made somewhat special perhaps by the proud awareness of having arrived at a new stage in life. However, the invitations to the dance soon lost their special character as uniquely belonging to this celebrative day; they became just an amusement like any other dance occasion. The best thing that came out of this celebration was possibly an improvised school paper of a humorous, satirical nature which held teacher and school in front of the mirror for harmless ridicule to the backward glancing eye, in the form of grotesque distortions which at once objectify things and provide an inner distance.

But on the whole these activities were no longer school celebrations. Students had to meet their needs outside school. And while they were doing this they were observed with the utmost suspicion. The most humorous forms of their amusements led, in their temerity, to conflict with their easily offended teachers. In some cases it even resulted in disciplinary actions. Seen from the school's point of view these carousals were something foreign. They arose from an alien initiative, and for the school principal the uneasy question presented itself of how far one could allow these pranks to go. These images had to be recollected to show the importance of the question of the meaning of ceremony and celebration. Even if today some things have changed from my school experiences, they have not changed very much.

A new trend in the school curriculum is the increased effort in music education. When one thinks about it, this emphasis on music should have given a strong new impulse to the idea of celebrations. Musical expression and amateur dramatic performances demand a festive occasion in which all the efforts of practicing can come to the highest fruition before an audience. But even these impulses were only reluctantly and hesitantly accepted into the total school scene, and they have had hardly any influence in bringing ceremonies and celebrations to their rightful place in the curriculum as worthy components of school life. 
Also completely missing today are theoretical reflections on the essential meaning of such festivities and their significance to the whole of education. A few fruitful beginnings are found in the older pedagogical literature-some by the Philanthrops, some by Jahn and the start of the physical education movement, in work by Frobel, and in the literature inspired by the Romantics. But in the subsequent era these ideas were not developed further, and so today we are totally lacking any pedagogical theory of ceremonies and celebrations.

In today's educational thought, ceremonies and celebrations are condemned to a poor Cinderella existence. Celebrations are not something to which one would have attached significance and which one would have implemented in one's own teaching; rather, they are something which one puts up with in practice, so that, so it seems, one can cope with the unruly demands of students. Festive events are seen to be an outlet for culpable pleasure seekers. One therefore puts up with them as a necessary evil. One sees them possibly as a form of compensation. Just as one gives children some chocolate if they have been obedient, so one permits a class a school party as a reward for all the hard work and efforts during the school year. At present, parties or festivities appear to have no educational function of their own and thus they remain pedagogically incomplete.

Yet one should recognize that ceremonies and celebrations have an indispensable function in human community, and what is of special concern for us here, in school life. They are neither merely concessions to human pleasure seeking nor just rewards for work performance. They are indispensable dimensions of human living without which life cannot be complete. They are therefore also necessary aspects of education, and their special function and form must be acknowledged from the point of view of education. In this vein, we must first inquire succinctly into the common anthropological function of ceremonies and celebrations so that the special pedagogical consequences may arise from these findings.

\section{The Anthropological and Pedagogical Significance of Ceremonies and Festive Celebrations}

We have talked about the notion of ceremonies and festive celebrations without making distinctions between the two. This corresponds to the common usage which employs them interchangeably. One says that one should festively celebrate ceremonies as they happen. Despite this, one must not ignore the difference between ceremonies and festive celebrations. One 
speaks of funeral ceremonies but not of funeral festivities. A sad event cannot also be a festive one.

We appreciate the differences best if we independently pay attention, not to the specific objects of the ceremony or the festive celebration, but to the special moods of the various events: A ceremonial mood is different from a festive mood. The ceremonial mood is carried by solemnity and by a certain darkness and heaviness. Loud words and happy laughter die, and the free movements of life feel hemmed in. Something obstructive hangs over everything. Therefore, one no longer moves in the accustomed manner; all hurry and haste is halted. One strides only in a measured tempo. Even speech is transformed. The careless use of everyday speech has become impossible. A special ceremonial style of speech, even a special vocabulary (as, for example, in saying strides instead of walks) arise. If the solemnity of the ceremony is pushed too far, then the danger arises that it passes into the laughable; consequently, irrepressible laughter may destroy the ceremonial mood.

Solemnity is the mood of ceremony in which authority finds itself. Here one encounters the fuller and deeper significance of life. That is why ceremonies are, above all, memorial ceremonies. One is to remember a past event, something historical, or the birth of a significant person. Through the ceremony the person becomes directly present to us, as is possible only in thoughtful reflection. This event is not just grasped in a theoretic sense; rather, it is immediately present to us in its signifying power. The distinguishing characteristic is that one steps out of the world of everyday life and into the solemn world of the ceremonial mood.

The experience of ceremonial solemnity is itself a crucial life experience; on any particular occasion one experiences in it the deeper significance of life-the historical foundation from which human life sprouts forth. And the ceremony is at the same time the only modality in which such an experience reveals itself. Only in the respectful observance of ceremony can greatness be experienced in its fullness. Therefore, ceremony is not possible in just any kind of situation; it can only be encountered in those situations where we experience directly the force that supports human life. We can say in a conclusive way about ceremonies that we ground ourselves anew in the supporting foundations of our historical lives. Indeed, the lived experience of ceremony is a deeply historical experience. This applies equally to the great communal ceremonies which deal with broad historical events as to the smaller-scale ceremonies which signify for an individual person a decisive point or pas- 
sage into a new phase of life. In the narrower realm of schooling this is also true for the graduation ceremony after having passed examinations. The significance of this event is not just abstractly brought to consciousness; it is experienced in its immediacy by partaking in the solemnity of the ceremonial mood.

Thus the ceremony is not just the outer adornment of life which one can do without and which those who have good sense would gladly like to renounce; it also has a deeply needful life function. Out of this insight arises the starting point for the pedagogical process. The ceremony is not an irrelevant issue which the school can dismiss with a sleight of hand. Instead it should be carefully and consciously cared for in its uniqueness. Greatness can only reveal itself in the ceremonial situation; thus it should be heedfully practiced.

We must be mindful, however, that ceremonies are foreign to children, and so their special significance cannot be taken for granted. Ceremonial solemnity stands in contrast to the child's as yet naive sense of life. Indeed, in its strangeness, solemnity can stimulate the child's propensity to imitate without grasping the deeper significance of the ceremonial act. However, this unchildlike character of ceremony does not imply that ceremonies have no place in the lives of children. On the contrary, as with wider life experiences, the child must be taught the deeper meanings that ceremonies hold in life. In particular, the child has as yet little fundamental awareness of deeper insights that are given to us by our sense of the finitude of life: insights concerning the historicity of human life, the grateful and trusting sense of being born and embraced by human tradition. Thus the ceremonial functions deserve a place on the educational agenda in order to stimulate and strengthen the child's historical consciousness.

Because the ceremonial function is foreign to children they cannot generate ceremonies themselves by giving meaning to them and by actively conducting them. Rather the ceremonial remains only available to the child. In this sense the ceremony moves closer to the realm of instruction, for it is the adults who create the conscious awareness of the ceremony for the child and who must carefully guide the child to these important experiences of life. The ceremonial becomes a significant opportunity for formative education. In the first place this means that school ceremonies should be taken seriously by adults. They must keep a cautious eye on all those things which could counteract the influence of the ceremonial. The teacher must therefore treat ceremonies seriously. Any neglect must be carefully 
avoided. On the positive side, one should guard the idea that ceremonies in their peculiarities, and in their distinctiveness from everyday life, must be consciously developed. The lower style of the purposeful dealings of everyday life and the higher style of the ceremonial speech and of the corresponding behavior at ceremonial functions are easy to separate and keep apart in their distinctiveness. That is why even the music at a ceremonial function is not an external adorning accompaniment. It has essentially the task to attune people to the ceremonial, to free people from the day-to-day rut, and to prepare them inwardly to accept that what is meaningful, and, after the moment of celebration, to bring it to a conclusion and to allow the people to return to their normal lives.

\section{The Anthropological Meaning of Festive Celebration}

If one has envisioned the essence of ceremony in the way described above, then one is ready to draw out the distinct nature of festive celebration. It is best to start again with the notion of festive mood and to try from there to approach its deeper anthropological meaning. In the festive atmosphere all the solemnity and heaviness of the ceremonial disappear. Festive colors are pale and bright, while the color black associated with ceremony is completely missing. The festive auditorium therefore has a completely different character from the mood of remembrance of the vaulted ceilings of the church ceremony. Even the movements and gestures of people are freed from burdens and solemnity. In festive celebrations one hears effervescent speech and joyful laughter. People move freely, lightly, and gracefully. Festive celebrations too require music, but this music has quite a different tone from the solemn character of ceremonial music. And finally, the festive celebration fulfills itself in the dance. In fact, the dance can be seen as the purest and most developed form of the celebration.

Just like the ceremony, the festive celebration is more than a mere outer adornment of life or a break after a period of hard work. Rather, we need to grasp the notion of celebration in its deeper significance, as a necessary function in human life. We experience it best, again, in the results of the mood of celebration, in the festival itself. The festive mood too has its peculiar creative power. However, it does not exist, as in the ceremony, in its own enhanced significance, but rather in its relationship to the world and to other people.

We orient ourselves now to the question of how festive celebrations are given to us in their primordial human form, and we can apprehend this especially well in extreme cases. With primi- 
tive people, according to ethnographers, festivals play an extraordinary role, and they usually end only after complete exhaustion. Similarly, Nietzsche (1922) says of the Dionysian festival of the Greeks:

Under the spell of Dionysius is not only the bond between human beings affirmed; also the alienated, antagonized, or subjugated world of nature celebrates again her festival of reconciliation with her lost son, the human being... Now through the Evangelism of a harmonious world every human being feels not just united, adopted, melted together with his or her neighbour, rather the human being feels as one. (p. 52)

What arises in the last metaphysical heightening is true also, although in a limited way, for every modern festive celebration, and it is expressed especially in the festive dance: The human being moves out of the isolation of his or her everyday existence into a situation of great bliss and finds himself or herself accepted into a new communion. It is not just that the experience of this communion brings the person deep happiness; it is, on the contrary, that the enhanced mood of the festive situation allows him or her to experience this communion. One must therefore even today signify the festive celebration as a metaphysical experience, that is, as one of the deepest experiences that can befall a person.

\section{The Pedagogical Implications}

At this point we cannot further explore the metaphysics of the festive celebration and the religious foundation out of which it arises. We cannot even explore here any further the deeply significant changes in communal consciousness involved in the dance. In this text we are concerned with the educational point of view, and so we are limited to examining the significance of the festive celebration within the school context. And because we are focusing on the school we will deal mostly with relatively minor festivals. But these school celebrations must not be belittled; they should be grasped and articulated in their own essential character. In comparison to the ceremonial, the festive qualities of life are not foreign to the child; they arise naturally, as inevitable expressions of the child's life. So far it is already a form of children's life, even if children's festivals are typically different from adult festivals. Still, despite all differences, it may be helpful to look again at the more exalted forms of festivals, for only from them can we understand the uniqueness of even the lesser and tamer festivals. With this in mind, I now suggest a few succinct pedagogical implications. 
1. The pedagogical sense of festive celebrations (as for ceremonies) does not lie embedded in the preparation time, so that, for example, the excited anticipation of the child can be used to practice the talents required for musical, choral, or dramatic presentations. Festive celebrations and solemn ceremonies are not some sort of nail on which the crafty teacher can hang any old objective which may be foreign to the festival itself. The significance of the celebration lies in the festival itself, in the experience of living through this extraordinary event.

2. Its significance lies next in the lasting interruption and in the resulting rhythm of the passage of time. One of the dangers of the modern work world is that it tends to fracture the division of time into a sequence of uniformly passing days, which, when we become accustomed to them, roll by ever more quickly, more hastily, and more tiring. Life uses itself up and expires finally in this monotonous flow. In the festive celebration, however, time comes to a standstill, not just in the sense of a rest or in the sense of a makeshift pause to catch one's breath, but rather in the deeper sense of an immediately experienced reimmersion into a timeless existence.

In a small measure, that is still the function of Sundays, and it is important enough to allow this to be experienced as an actual niche in which a person can come to complete rest, and not as an opportunity to catch up on pressing responsibilities. Even the special consideration given to Sundays is therefore an important concern for the bodily and especially the spiritual/mental health of people. Even though this consideration is largely an affair of the family, the school must do its utmost to put a stop to the tendency to do away with the special meaning of Sundays. This is important especially, of course, with large celebrations, particularly the great Christian holidays. They break up the year which then stops being a monotonous sequence of days. People live from week to week, from day to day, with the festive times in mind, and they return to the everyday in a manner that is strengthened by them. People become rejuvenated through festive celebrations, and by their beacons time is experienced as an orderly unity. It is only through such wholeness that a healthy life is possible. Even though these large festive celebrations can only be a responsibility of the school to a small degree, the school must do its part to include this rhythm of time in its work and to allow children to experience it.

3. Somewhat different are those festivities which are celebrated within the school and which are therefore the special responsibility of the school. They are, of course, small celebrations in comparison, but even these must be thoughtfully and carefully 
planned and realized. Even if the festive celebrations stretch the limits of good planning and even if the festive activities, because of their effusiveness, boil over these limits, even then should these limits be carefully contemplated so that one can recognize them as well as know where the limits of the sensible and functional have turned into negligence and degeneration. Nothing is harder to achieve than such a moment of high lifefulfillment. And just such an experience should not be left to chance by the educator.

4. A typical feature of festive celebrations is extravagance and boisterousness. People feel themselves freed from and lifted above the limiting structures of everyday life and so they want to give expression to this feeling. There exist typical forms of festive extravagance such as the carnival and the masquerade. In the school, too, the need for free expression should not be anxiously limited. We know from stories of medieval school festivals how far this wantonness went, and we would not like to imitate these. But we should acknowledge the importance of these basic human needs and provide some room for them without worrying about the existence of established rules or holy regulations. It is here also that the need arises for jokes and satire in the midst of which someone often finds room to express bitter criticism under the guise of humorous dress-up clothes. But maybe these are special cases which are not tied directly to the essence of festive celebrations.

5. An important aspect of the festival, unlike that of the solemn ceremony, is that it cannot be experienced passively. It requires a spontaneous participation. Only through one's participation can one submerge oneself in this special mood which is so different from the consciousness of everyday life. That is why all the physical movement of festive celebrations has such great significance. They demand a free, unrestrained outpouring of activity. Thus we are given forms of dramatization, festive processionals, and finally the dance.

6. Generally, however, for a festival to be fully effective, it must happen that the person is lifted out of the narrow boundaries of his or her everyday existence, and that this person's individual life-experiences harmonize with a deeper foundation of life, through which, in turn, all the rational foundations of the experience of the festival are immediately accessible. It is in this sense that we are reminded of the above cited words of Nietzsche regarding the metaphysical experience of the festival. Even if the festive celebrations of the school do not reach all the way to this last boundary, it is still important to know about this backdrop in order to understand the fundamental experience 
which is possible in the school festival and which is important for the total communal life: the experience of a deeper communion among human beings which ensues in the festive mood as if on its own accord and out of its own inner necessity. In this experience one comes closer to one another, one feels joined together. Earlier formalities suddenly disappear and there develops a feeling of inner kinship, an inner communion, and it is such a sense of belonging together that fundamentally cannot be achieved in any other way and which endures even after the festive celebrations have subsided. When people meet again the next day at work they sense a new commonality. I have often experienced, in the realm of the university, how, after a successful seminar festivity, the whole class seems to be transformed and one only regrets that one didn't have the celebration earlier.

There is also a sense of community which develops through work, but which is limited only to the sphere of the workplace and which is apperceived by the person only as a reasonable, rational way to behave or act together. This is the social aspect of the workplace. But beyond this there is a deeper sense of community and togetherness which is fundamentally accessible only through the communal experience of the festive celebration and which is therefore also most significant for the community life of the school. In this respect the festive celebration has a direct educational function. It must be seen as something that is important in its own right and that is treated as suchand not as a means to another unrelated purpose (such as a practice of certain skills and competencies) and not as a reward or a bribe to give to children.

From this arises an inference that we must apply to the holding of festive celebrations in the school. If the previously mentioned effect of community is to come about, then the festival must be celebrated in a surrounding where people, even after the festival is over, can experience the sense of togetherness that the festival has brought about. That means that every festival has missed its essence if a large number of invited guests miss this sense of communion.

7. One should not dwell too much on the kinds of dance festivities that we know from our past and which deal more with adults (even though some things could be said about this problem). The life of the child is especially full of festive influences which must be recognized and understood. The young child is particularly impressionable to the effects of festivals. For example, a nightly processional with lanterns can be a powerful experience for small children. The kindergarten too has many possiblilities to bring the simple events of the year closer to a 
festive occasion. It is necessary that the adult realize that it is not enough to remain a cool, objective observer, but that he or she must actually participate and celebrate with the children.

\section{Wandering}

Finally, in the context of this discussion, we turn to the notion of wandering. If wandering can make claim to great anthropological and also pedagogical significance, then it is given this meaning through deep, far-reaching changes and rejuvenations of consciousness which the person experiences in wandering and which are similar in some ways to the experiences of festive celebrations. In some respects the effects of wandering are even more enduring because wandering is not restricted to as short a time span as festive events. Also in wandering, in the true comfortable walking on foot along narrow paths or quiet country lanes, a person, if he or she surrenders to this situation, can experience a kind of inner harmony and peace in which the continual goal-orientation of his or her professional life or school life falls away in the experience of infinitely deep contentment, a mood of timeless, purposeless, pure existence. Wandering, in this sense, is a deeply experienced return to the untroubled source of being and the rejuvenation of the person from his or her numbed rationalized life.

Wandering in this sense possesses an unparalleled pedagogical significance and must be cared for with that much more love, for it is unknown to a large portion of today's youth. Hitchhiking across the country, that modern and popular form of living on the road, can be no substitute for it. Even if the latter allows the experience of an unfettered, adventurous life and a rich measure of excitement and the unfamiliar (and that in itself is a plus) then the young person is still at the mercy or in the midst of the haste of the highway. In this mode the world is observed from the car, a quickly passing picture which remains unfamiliar and is soon forgotten. Traveling this way does not become a true contact with reality or an actual acceptance of and by nature. This happens only to those who choose to wander the quiet path, without haste, yes, without consciousness of time: those footwanderers who do not shy away from the occasional exploration of the limits of their bodily exertions. Here arises a worthwhile assignment for the caring adult, and it is all the more worthwhile as he or she must often find himself or herself in opposition to the prevailing tendencies and must accept the danger of being seen as old-fashioned. But the value of wandering is not just the special experience of a special generation which has passed through its youth movement. Rather, it is 
grounded in a timeless human nature and may gain in importance with the coming civilization.

In this context arises the significance of school excursions and school wanderings; even if in such undertakings as large groups of children we cannot talk of actual wandering, which only occurs for the individual or the smaller, close-knit group. Still, school wanderings are important. They are related to festive school celebrations in the sense mentioned earlier, and they should be perceived in this way: as an interlude in the uniform progression of time, as a relaxing of regular routines, as an opportunity for adventure for the exercise of physical energies, as a chance to rise to the level of abandon and carefreeness. And because it is so foreign to today's child and because, truthfully said, it is perceived even by many teachers as a burdensome duty, it is all the more important to take these excursions seriously, to find truly enchanting, exciting goals for the children, to include truly demanding trails, and above all, not to worry about time. This actual immersion into the joy of wandering, this pure living experience, does not fundamentally happen when one simply wants to get on with it and to return home as early as possible.

Such school outings will also lead to the same results of the creation of a mood of community that was described earlier in our discussion of the festive celebration. It may come unintentionally in the shared experiencing of joy and peace. It will simply come into existence and then linger productively into the future.

But as we have already noted, we cannot call these school excursions actual wanderings. For that type of lived experience to occur a kind of special reflection is necessary, like that which is only possible in individual or small group excursions. The experience of true wandering, then, cannot be the responsibility of the school. Here other formative influences like the family or the youth group must be involved. The most we can expect of the school is an indirect influence. One can, even without initiating or going along on an actual wandering experience, awaken the proper attitude or desire for it. One can create and encourage opportunities for wandering. In this way, the school too can play its part.

\section{Note}

Translated and edited by Max van Manen and Peter Mueller from O.F. Bollnow (1962/1970), Die Pädagogische Atmosphäre (5th ed.), Heidelberg: Quelle und Meyer Verlag (permission from publisher). 


\section{References}

Bollnow, O.F. (1955). Neue Geborgenheit. Das Problem einer Überwindung des Existentialsmus. Stuttgart: Verlag W. Kohlhammer.

Heidegger, M. (1927). Sein und Zeit. Halle a.d. Saale: Verlag M. Niemeyer.

Nietzsche, F. (1922). Klassikerausgabe. (1 Band). Leipzig: Verlag Alfred Kröner. 